\title{
Attention behaviours but not pain related behaviours are modified by the presence of a twin in lambs undergoing castration by rubber ring
}

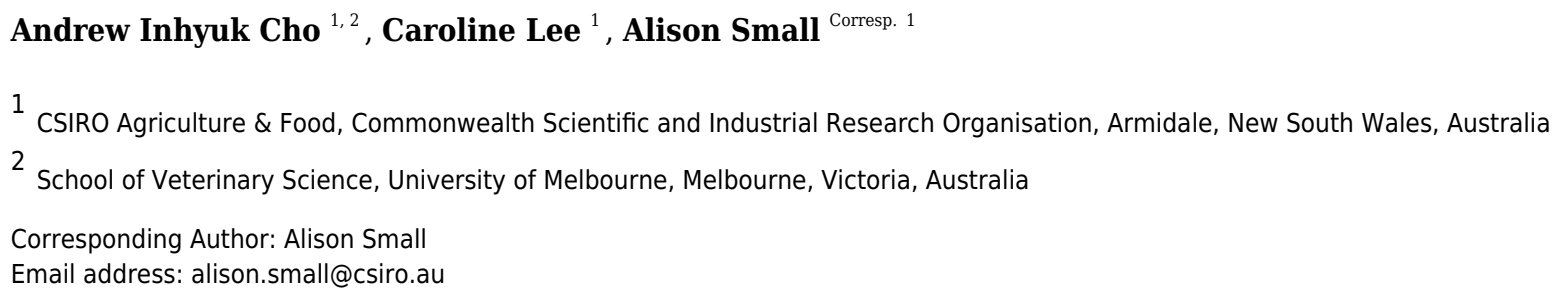

The social context of social species such as sheep can modify their physiological and behavioural responses to stressors, through social buffering and social facilitation. Social buffering can lead to amelioration of stress, while social facilitation can lead to stress responses in an observer animal in the presence of a conspecific in distress. The current study investigated twin lambs undergoing ring castration, grouped either homogeneously with a castrated lamb (actor), or heterogeneously with a non-castrated lamb (observer) to examine the impact of social grouping on behavioural responses. Each lamb was scored for two classes of behaviour: pain related behaviours and postures that are putatively related to the response to castration; and attentional behaviours directed at its twin. Thus, each lamb participated in the experiment as an actor exhibiting pain related behaviours and postures, and as an observer of its twin. When behaviours of lambs were assessed as actors, there was a significant $(P<0.05)$ effect of castration but no significant effect of social grouping on expression of pain related behaviours. When behaviours of lambs were assessed as observers, homogeneous grouping of castrated lambs increased attention towards the other twin in comparison to non-castrated lambs group homogeneously or lambs grouped heterogeneously $(P<0.01)$. Non-castrated lambs grouped homogeneously demonstrated significantly lower numbers of head direction changes $(P<0.001)$ and lower number of ear posture changes $(P<0.05)$ than heterogeneously grouped or castrated lambs. This study indicates that social attention between twin lambs is not clearly dependent on pain status of the actor lamb. It suggests that in order for the observer lamb to provide significant attention to the actor lamb displaying pain related behaviour, the observer lamb also needs to be experiencing pain concurrently. Furthermore, there is some evidence that the presence of pain related behaviours can lead to increased attention to the surrounding environment in non-castrated lambs. Understanding the effect of concurrent experience and varying social context assists us to improve our 
understanding of results of other experiments on pain-related behavioural responses. 
1 Attention behaviours but not pain related behaviours are modified by the presence

2 of a twin in lambs undergoing castration by rubber ring

3

4

5 Andrew Inhyuk $\mathrm{Cho}^{1,2}$, Caroline Lee ${ }^{1}$, Alison Holdhus Small ${ }^{1}$

6

$7{ }^{1}$ CSIRO Agriculture \& Food, Commonwealth Scientific and Industrial Research Organisation,

8 Armidale, New South Wales, Australia

$9 \quad{ }^{2}$ School of Veterinary Science, University of Melbourne, Victoria, Australia

11 Corresponding Author:

$12 \quad$ Alison Small ${ }^{1}$

13 CSIRO, Locked Bag 1, Armidale NSW 2350, Australia

14 Email address: Alison.small@,csiro.au

15

16 


\section{Abstract}

18 The social context of social species such as sheep can modify their physiological and behavioural responses to stressors, through social buffering and social facilitation. Social buffering can lead to amelioration of stress, while social facilitation can lead to stress responses in an observer animal in the presence of a conspecific in distress. The current study investigated twin lambs undergoing ring castration, grouped either homogeneously with a castrated lamb (actor), or heterogeneously with a non-castrated lamb (observer) to examine the impact of social grouping on behavioural responses. Each lamb was scored for two classes of behaviour: pain related behaviours and postures that are putatively related to the response to castration; and attentional behaviours directed at its twin. Thus, each lamb participated in the experiment as an actor exhibiting pain related behaviours and postures, and as an observer of its twin. When behaviours of lambs were assessed as actors, there was a significant $(\mathrm{P}<0.05)$ effect of castration but no significant effect of social grouping on expression of pain related behaviours. When behaviours of lambs were assessed as observers, homogeneous grouping of castrated lambs increased attention towards the other twin in comparison to non-castrated lambs group homogeneously or lambs grouped heterogeneously $(\mathrm{P}<0.01)$. Non-castrated lambs grouped homogeneously demonstrated significantly lower numbers of head direction changes $(\mathrm{P}<0.001)$ and lower number of ear posture changes $(\mathrm{P}<0.05)$ than heterogeneously grouped or castrated lambs. This study indicates that social attention between twin lambs is not clearly dependent on pain status of the actor lamb. It suggests that in order for the observer lamb to provide significant attention to

37 the actor lamb displaying pain related behaviour, the observer lamb also needs to be experiencing pain concurrently. Furthermore, there is some evidence that the presence of pain related behaviours can lead to increased attention to the surrounding environment in uncastrated 
40 lambs. Understanding the effect of concurrent experience and varying social context assists us to

41 improve our understanding of results of other experiments on pain-related behavioural responses.

\section{Introduction}

43 Understanding social influences on behaviour is a vital component to measuring welfare states

44 in social animals such as sheep (Colditz et al., 2012). It is currently understood that pain changes

45 the animal's physiology and behaviour (Molony and Kent, 1997) and the behaviour of animals

46 can be influenced by their social context (Dall et al., 2005). Thus, alteration of the animal's

47 behaviour in response to pain can also be dependent on the social context. Animals experiencing

48 pain may invoke similar pain-related behavioural responses in bystander animals that have not

49 received physical trauma via a process such as social facilitation (also called social contagion)

50 (Nicol, 1995). Social facilitation is a term used to define a situation where the behaviour of one

51 individual induces the same behaviour in another individual (Nicol, 1995).

52 Alternatively, the intensity of the behavioural and physiological responses of an animal to a

53 physical trauma such as castration could be reduced by the presence of non-traumatised pen-

54 mates by a mechanism such as social buffering (Nicol, 1995, Hennessy et al., 2009, Kikusui et

55 al., 2006, Veissier et al., 1998). Since it is advantageous for the individuals to engage in

56 behaviour to promote survivability of others with similar gene composition (Hamilton, 1964), it

57 is no surprise that ewes are more attentive to their offspring experiencing pain (Hild et al., 2011).

58 The mechanism of increased attention may be due to emotional contagion, where a convergence

59 of emotional states between individuals occurs and this results in increased maternal care (Hild et

60 al., 2011). Social buffering of pain behaviours in lambs has been demonstrated to depend on the

61 relationship between the actor and observer (Guesgen et al., 2014a). For this reason, our study 
62 utilised twin lambs. Social buffering of the physiological and behavioural response to stress has

63 also been demonstrated by providing a picture of a conspecific to isolated sheep (da Costa et al.,

64 2004). Social support plays an important role in buffering the effects of stress and has important

65 implications for farm animal welfare as reviewed by (Rault, 2012).

66 Behavioural indicators of pain in lambs in response to painful husbandry procedures are well

67 established. These include changes in active pain related and postural behaviours (Paull et al.,

68 2012), the number of ear posture changes (Guesgen et al., 2016) and attention (Hild et al., 2011).

69 This study investigated whether the social context of twin siblings influences the behavioural

70 responses to pain. We predicted that in twins, the presence of a non-castrated lamb (observer

71 lamb) with a castrated lamb (actor lamb) would reduce the expression of pain related behaviours

72 in the actor lamb through social buffering, while an observer lamb would demonstrate increased

73 pain related behaviours in the presence of a castrated sibling through social facilitation.

75 Materials \& Methods

76 The experiment was performed at CSIRO's FD McMaster Laboratory, Armidale, NSW,

77 Australia and was approved by the Institutional Animal Ethics Committee, ARA 14/14.

78 The study followed methodology previously utilised in a similar study (Colditz et al., 2012), as

79 outlined below.

80 Animals and treatments

81 Forty-eight male fine wool Merino lambs born as twin lambs and their mothers were used for

82 this experiment. Lambs were born in spring of 2014 at pasture following natural mating. Dates of 
83 birth were not recorded at birth, so mother-offspring and twin pairs were identified in the field by

84 observation of proximity, following and suckling behaviour at the end of the 5-week lambing

85 period. Selection criteria were that the ewes and lambs appeared clinically healthy, lambs were

86 vigorous in following the ewe and the lamb suckling was well tolerated by the ewe. Animals

87 were inducted into the animal house in the week prior to the trial to acclimatise to the treatment

88 environment, and they were fed sheep pellets (Ridley Agriproducts, Tamworth, Australia; 20.6\%

89 crude protein DM; $12.5 \mathrm{MJ} / \mathrm{kg} \mathrm{DM}$ ) at a rate of $0.8 \mathrm{~kg} /$ dry sheep equivalent/day and $100 \mathrm{~g} /$ day

90 oaten chaff. Lambs had an age between 6 to 12 weeks and bodyweights ranging from 14.0 to

$9122.8 \mathrm{~kg}$ on the day prior to treatment. In addition, lambs were weighed on entry to the animal

92 house and divided into 3 cohorts of 16 lambs, stratified by average weight of the twin pair.

93 Within each cohort, twin pairs were randomly allocated to treatment groups. During acclimation

94 to the animal house environment, each cohort of 16 lambs were housed in a large group pen

95 together with their mothers. On the day prior to treatment the lambs underwent a clinical

96 examination and blood sampling for health screening, were weighed, the identification marks

97 applied to the flanks, and placed into their assigned treatment groups of two ewe-lamb-lamb

98 units into each observation pen. Mother-offspring units in which any animals did not appear

99 clinically healthy or did not return normal values of heart rate, respiratory rate, rectal temperature

100 and haematology including differential white blood cell count on the day prior to treatment were

101 to be excluded from the study: this did not occur.

102 Four treatment pens were used for each cohort, each treatment pen consisting of two ewes with

103 their respective twin offspring. Both twin pairs in each treatment pen received the same

104 treatment as follows: homogeneous grouping (both twins ring castrated (CC, positive control) or

105 both twins non-castrated (NN, negative control)), heterogeneous grouping (ring castrated lamb 
106 observing a non-castrated lamb $(\mathrm{CN})$ and non-castrated lamb observing a castrated lamb (NC)),

107 such that each cohort contained two pens of heterogeneous pairings, and one each of non-

108 castrated and castrate homogeneous pairings. I.e. there were $4 \mathrm{NC}$ pairs per cohort, so a total of

10912 NC pairs in the analysis. Within each pairing both lambs were evaluated as both 'observer'

110 and 'actor' for the purposes of the study (Figure 1), leading to $n=12$ in each observer-actor unit

111 (C observing C, N observing N, N observing C, C observing N). Ewe-offspring groups were

112 randomised to treatment group by blinded selection of a coloured marble from a cloth bag, the

113 marble colour being pre-assigned to treatment using a similar approach.

115 Figure 1 here

117 Cohorts were tested sequentially over 9 days, such that on the completion of one cohort of

118 observations, those animals were removed from the treatment pen on the subsequent morning

119 and the pen cleaned (Table 1). On the following day, the next cohort was prepared and placed

120 into treatment pens, so that they adjusted to the treatment pens overnight with treatment applied

121 the following day.

123 Table 1 here

125 Allocation of treatment group pairings to treatment pens were different for each cohort to control 126 for potential pen effects. The pens were as described by Colditz et al. (2012): $4.4 \times 3.0 \mathrm{~m}$ with 
127 slatted wooden floor, with visual contact between pens limited through use of opaque hessian

128 cloth and rubber mats on the vertical surfaces, but animals could still hear one another between

129 the social groups. The order of treatment of pens was selected to minimise distraction to groups

130 that had previously been treated, and behaviour observations were underway.

131 Lambs were placed in dorsal recumbency in a lamb marking cradle for approximately one

132 minute for their treatment. Ring castration was performed according to the standard industry

133 practices (Lloyd and Playford, 2013), without analgesia or anaesthetic drugs. Non-castrated

134 lambs had their scrotum manipulated for a similar period of time to the time required to apply the

135 elastrator ring, without a ring being applied. Within the heterogeneous pairings, the selection of

136 the castrate versus the non-castrate animal in each pair was randomised by blind selection of a

137 coloured marble from a cloth bag. Treatments were administered approximately between 08:45

138 and 09:30 h with each pair of twins treated every 5 minutes to allow time for ear posture video

139 recording of each ewe-offspring group.

140 Continuous video footage of each pen was captured from 08:00 to 14:00 h by two video cameras

141 per pen (Samsung Day And Night Digital Color Camera, Model SCC-B2313P, no city disclosed

142 by manufacturer, China). Additionally, 1 min each of twin lambs and the respective ewe was

143 captured by hand-held digital video recorder (Sony Handycam, Model HDR-XR260E, no city

144 disclosed by manufacturer, Japan) 10 minutes after the lamb was placed back in the pen for ear

145 posture assessment. From this footage, 30s of video was selected for ear posture analysis per

146 animal. However, due to the poor quality of video obtained from the handheld position of the

147 camera, it was not possible to identify specific ear postures as described by others (Gavva et al.,

148 2008, Verbeek et al., 2012, Reefmann et al., 2009a), therefore only data on the number of times

149 the ear posture changed was collected. Data collection was carried out by a single observer, 
150 blinded to treatment, and a subset of 2 videos from each cohort were assessed by a second

151 blinded observer to verify reliability of counting ear posture changes. Animal were fed at 08:00

$152 \mathrm{~h}$, the feeding process taking 10 minutes, so that observations were not modified by feeding

153 behaviours. In the following day, the ewes and lambs were removed from the study pens, the

154 pens were cleaned and the next cohort of sheep were moved into the pens.

\section{Behavioural data and statistical analyses.}

156 Each lamb within a pen was identified by one of four symbols marked on the wool of the lamb

157 using spray marker (Steadfast Stockmark, Dymark, Australia). Allocation of symbols were

158 randomised so that the observer was blinded to castration treatment. Video footage of each lamb

159 was recorded for $5 \mathrm{~h}$ after treatment applications were completed, using a digital video recorder

160 (Pacific Communications, Port Melbourne, Victoria, Australia), but for the current study,

161 attention was focused on the first 45 minutes post castration. The ethogram used in this study

162 was based on behaviour patterns described in previous studies (Grant, 2004, Kent et al., 1998,

163 Colditz et al., 2012) of behavioural responses of lambs following ring castration . Detail of the

164 ethogram, the behaviour codings used and the calculations used to determine combined totals

165 (e.g. total upright and Sum of Pain Related Behaviours) is presented in Table 2. Video footage

166 was assessed offline using SmartViewer software (Hanwha Techwin America, NJ, USA). Counts

167 of postural behaviours and active pain related behaviours performed by each lamb in a

168 continuous block of 30 min (15 to 45 min after treatment) were manually collected in MS Excel

169 (Microsoft Inc.) by a single observer. A subset of 2 videos from each cohort were assessed by a

170 second blinded observer to verify reliability of data collection. The attention direction behaviours

171 are described as shown in Table 3. Attention direction behaviours were categorised as the time 
172 spent looking towards specific targets as described by Monk et al. (2019) and were observed for

173 seven 1-minute periods at 5 min intervals from 15 to 45 min post castration.

174 Results for postural behaviours, active pain related behaviours and ear posture changes were

175 calculated as counts of each behaviour, and results for attention behaviours were calculated as

176 sum of time spent looking towards specific targets.

177 Data were collated in MS Excel (Microsoft Inc.) analysed using ASREML (VSN International,

178 Hemel Hempstead, UK), using a linear fixed-effects regression model including treatment,

179 cohort, pen and first order interactions. Where necessary, behavioural data were normalised for

180 analysis of variance. Logarithmic transformation was required for the attention direction

181 'Looking at own tail' and all postural and pain-related behaviours. In some categories of

182 behaviour, there were insufficient data for analysis therefore these were pooled into the 'Sum of

183 Pain Related Behaviours' category. Rolling (R1), jumping (Jmp) and headshake (Sh) were not

184 analysed individually due to low frequencies but were used to calculate total abnormal

185 behaviours. 95\% confidence intervals were calculated as the mean +/- 1.96 SEM to determine

186 treatment differences; $\mathrm{P}<0.05$ was considered significant.

Table 2 here

189

Table 3 here

191

192 Results 
193 Behaviour as actors: Pain related and postural behaviours.

194 There was a significant $(\mathrm{P} \leq 0.05)$ effect of castration treatment on Sum of Pain Related

195 Behaviours (Table 4), and a significant effect of cohort on normal lying (N1), kicking/foot

196 stamping (Fsk); and Licking/biting wound site (Lbw). However, there was no significant effect

197 of social grouping on any pain related behaviours and no significant interactions between

198 treatment and pen, treatment and cohort or pen and cohort.

\section{Behaviour as observers: Attention direction}

201

202

203

204

There was a significant $(\mathrm{P}<0.05)$ effect of treatment on attention to twin, attention to tail, attention elsewhere and changes in attention direction, and no significant interactions between treatment and pen, treatment and cohort or pen and cohort. For looking at ewe, there were no significant main effects or interactions (Table 5). When both twin siblings were castrated, they displayed increased time looking at the other twin $\left(\mathrm{F}_{3,33}=5.04, \mathrm{P}=0.006\right)$. When twins were homogeneously grouped, the castrated lambs showed increased time looking at their own tails than non-castrated lambs $\left(\mathrm{F}_{3,33}=6.17, \mathrm{P}=0.002\right)$. When both twin siblings were non-castrated, they demonstrated significantly lower number of head direction changes as compared to heterogeneously grouped twins, or those where both twins were castrated $\left(\mathrm{F}_{3,33}=10.27, \mathrm{P}<\right.$ $0.001)$.

\section{Table 4 here}

\section{Table 5 here}




\section{Ear posture changes}

217 Other than a decreased number of ear posture changes $\left(\mathrm{F}_{3,33}=3.67, \mathrm{P}=0.022\right)$ displayed when

218 both twin siblings were non-castrated, there were no differences between treatments, no

219 significant main effects and no significant interactions between treatment and pen, treatment and 220 cohort or pen and cohort.

\section{Discussion}

223 In this study, lambs undergoing castration were grouped either homogeneously with a castrated

224 twin, or heterogeneously with a non-castrated twin to examine the impact of social grouping on

225 behavioural responses to painful husbandry practices. Regardless of social grouping, castrated

226 lambs showed a significant increase in all pain related behaviours as well as increased changes in

227 posture. These differences are consistent with previous studies that have investigated

228 behavioural responses of lambs to painful husbandry procedures (Grant, 2004, Colditz et al.,

229 2012, Paull et al., 2012).

230 While it was predicted that the presence of a pain-free twin would provide social buffering to

231 reduce pain-related behaviours in castrated lambs, this was not found to be the case. The results

232 indicate that the presence of a twin sibling with a different treatment did not substantially modify

233 the responses to the castration treatments via social buffering or contagion. Similarly, Colditz et

234 al. (2012) found that heterogeneous mixing of lambs that were sham handled, surgically

235 castrated or ring castrated did not substantially alter the behavioural responses to the specific

236 castration treatment. There may, however, be an effect of the specific relationship between the

237 lambs that was not possible to examine in our study as all subjects had both a twin and ewe 
238 present. A recent study comparing social buffering of pain behaviours in response to tail docking

239 showed significant differences between twin lambs and unrelated lambs where the pairs of twins

240 displayed lower frequency of kicking and rolling than pairs of unrelated lambs (Guesgen et al.,

2412014 b). As the current study's results show no behavioural difference between homogeneous

242 grouping (CC) and heterogeneous grouping ( $\mathrm{CN}$ or $\mathrm{NC})$, it can be suggested that the effect of

243 social buffering is more dependent on the presence of a relative rather than the pain status of the

244 observer lamb. Interactions between treatment (castrated or non-castrated) and social grouping

245 were not significant for any pain related and postural variables.

246 It cannot be ruled out that the sensitivity of the behavioural measures used in our study may not

247 have been high enough to detect subtle behaviours displayed by twin lambs. Other potential

248 measure such as distance between lambs and facial expressions should be investigated in future

249 studies. Furthermore, we cannot exclude the dam's influence on pain behaviour (Hild et al.,

250 2010) which may have masked the social interaction between lambs.

251 In addition to the analysis of active pain related and posture of lambs as actors, attention directed

252 behaviour and ear posture changes of lambs as observers were investigated as additional

253 indicators between twins of different social grouping. When both twins were castrated, twins

254 showed a significant increase in the amount of time spent looking at their twin in comparison to

255 all other social groupings. This indicates that the observer lamb was more attentive to its twin

256 sibling when in pain, only when the observer lamb itself was also simultaneously experiencing

257 pain. Attentiveness has been previously measured in ewes towards lambs that are in pain, and

258 exploring and glancing have been identified to be directly correlated with the level of lamb's

259 pain behaviours (Hild et al., 2011). This is consistent with our finding that attention direction

260 behaviour is increased when both twin lambs are castrated and in pain but there were no 
261 differences in attention direction behaviour when only one twin was in pain. It may be that for

262 lambs to show increased attention towards a twin in pain, they need to be experiencing the state

263 of pain concurrently. This may be a form of emotional empathy as the lamb is reacting to the

264 observed experiences of the other. Related chickens have been demonstrated to be capable of

265 emotional empathy with mother hens being responsive to their chicks' distress (Anand and Bley,

266 2011), but emotional empathy was not found in unrelated hens (Wu et al., 2008). It may also be

267 that emotional contagion is occurring with a convergence of emotional states between the lambs

268 as has been suggested as a mechanism for increased attention by ewes towards castrated lambs

269 (Hild et al., 2011).

270 The finding of decreased head direction changes (changes in attention) when both twins were

271 non castrated aligns with the ear posture changes which were significantly lower in non-castrated

272 twin siblings in comparison to other social groups. This suggests that non-castrated lambs placed

273 with other non-castrated lambs in the same pen environment have lower alertness or attention

274 towards their surroundings in comparison to castrated lambs. Conversely, this highlights that a

275 non-castrated lamb placed with a castrated lamb in pain demonstrated heightened alertness to the

276 surrounding environment, similar to the castrated sibling.

277 It is known that acute stress and pain induces activation of the sympathetic nervous system and

278 hypothalamic-pituitary-adrenal (HPA) axis (Tsigos and Chrousos, 2002), resulting in release of

279 corticotropin-releasing hormone $(\mathrm{CRH}) . \mathrm{CRH}$ in the hypothalamus appears to mediate

280 anxiogenic behaviour including heightened alertness (Reefmann et al., 2009b, Reefmann et al.,

281 2009c). Indeed, pharmacological induction of anxiety altered attention and vigilance behaviours

282 in sheep (Monk et al., 2018) and hence, increased head direction and ear posture changes in all 
283 castrates was an expected result. However, the mechanism of social influences on pain and stress

284 from castrated lamb to non-traumatised lamb leading to increased alertness is unclear.

285 It is possible to attribute the influence of behaviour of heightened attention to an instinctive

286 evolutionary mechanism to increase the probability of survival in nature (Decety et al., 2016). As

287 mentioned in the introduction, it can be seen as a behavioural mechanism to increase the

288 preservation of genes by increasing the chance of survival of individuals with similar genetic

289 make-up. However, due to the limitations of this experiment, it is difficult to conclude whether

290 this social influence on attention directed behaviour in response to pain is specific to twin lambs.

291 This was the first study to utilise handheld video recording to investigate ear postures in a pen

292 situation. While distinct ear postures have been linked with differing emotional states in sheep

293 (Boissy et al., 2011, Reefmann et al., 2009a), unfortunately, it was very difficult to capture

294 footage of both ears at the same time, and the video was not recorded from enough height to

295 perceive the depth of the ears' position in relation to the skull. However, it was possible to

296 identify ear posture changes, hence only the data for ear posture change was presented. A study

297 in lambs undergoing the painful procedure of tail docking reported an increased number of

298 changes in ear postures was observed in response to tail docking (Guesgen et al., 2016), however

299 we observed few differences in ear posture changes in the current study. Use of the hand-held

300 recording technique may have affected the behaviour of the animals, although the cameraperson

301 made effort to move slowly around the edges of the pen and remain unobtrusive. Prior to

302 treatment, the animals had been subject to one week of acclimation to the animal house

303 environment including movement of personnel in and out of the pens to reduce the effect of

304 personnel activity on the animals' behaviour. 
305 Further research is required to explore the effects of animal temperament, breed type and age of

306 lamb on social transmission of behaviours. In terms of age, the lambs in this study ranged from 6

307 to 12 weeks of age, after the reported period in which rapid change in behavioural responses to

308 pain occurs (Guesgen et al., 2011, Johnson et al., 2009, McCracken et al., 2010).

309

\section{Conclusions}

311 This study found no evidence of social buffering in twin lambs with their mother present as there

312 was no significant decrease in pain related behaviours and postures in lambs in company of a

313 pain free twin. There is some suggestion that in order for the observer lamb to provide significant

314 attention to the actor lamb displaying pain related behaviour, the observer lamb also needs to be

315 experiencing pain concurrently. Furthermore, there is some evidence that social transmission of

316 pain behaviours may lead to increased attention towards the surrounding environment.

317 Understanding the effect of concurrent experience and varying social context assists us to

318 improve our understanding of results of other experiments on pain related behaviour.

\section{Acknowledgements}

321 This work was supported by Australian taxpayers through federal government appropriation

322 funding of CSIRO. We thank Dominic Niemeyer, Troy Kalinowski, Tim Dyall, Aymeric de

323 Trogoff du Boisguezennec, and Anna Wilson for technical assistance.

325 References 
ANAND, P. \& BLEY, K. 2011. Topical capsaicin for pain management: therapeutic potential and mechanisms of action of the new high-concentration capsaicin $8 \%$ patch. British Journal of Anaesthesia, 107, 490-502.

BOISSY, A., AUBERT, A., SIR, L., GREIVELDINGER, L., DELVAL, E. \& VEISSIER, I. 2011. Cognitive sciences to relate ear postures to emotions in sheep. Animal Welfare, 20, 47-56.

COLDITZ, I. G., PAULL, D. R. \& LEE, C. 2012. Social transmission of physiological and behavioural responses to castration in suckling Merino lambs. Applied Animal Behaviour Science, 136, 136145.

DA COSTA, A. P., LEIGH, A. E., MAN, M. S. \& KENDRICK, K. M. 2004. Face pictures reduce behavioural, autonomic, endocrine and neural indices of stress and fear in sheep. Proceedings of the Royal Society B-Biological Sciences, 271, 2077-2084.

DALL, S. R. X., GIRALDEAU, L. A., OLSSON, O., MCNAMARA, J. M. \& STEPHENS, D. W. 2005. Information and its use by animals in evolutionary ecology. Trends in Ecology \& Evolution, 20, 187-193.

DECETY, J., BARTAL, I. B., UZEFOVESKY, F. \& KNAFO-NOAM, A. 2016. Empathy as a driver of prosocial behaviour: highly conserved neurobehavioural mechanisms across species. Philosophical Transactions of the Royal Society B-Biological Sciences, 371, 20150077.

GAVVA, N. R., TREANOR, J. J. S., GARAMI, A., FANG, L., SURAPANENI, S., AKRAMI, A., ALVAREZ, F., BAK, A., DARLING, M., GORE, A., JANG, G. R., KESSLAK, J. P., NI, L., NORMAN, M. H., PALLUCONI, G., ROSE, M. J., SALFI, M., TAN, E., ROMANOVSKY, A. A., BANFIELD, C. \& DAVAR, G. 2008.

Pharmacological blockade of the vanilloid receptor TRPV1 elicits marked hyperthermia in humans. Pain, 136, 202-210.

GRANT, C. 2004. Behavioural responses of lambs to common painful husbandry procedures. Applied Animal Behaviour Science, 87, 255-273.

GUESGEN, M. J., BEAUSOLEIL, N. J., MINOT, E. O., STEWART, M., JONES, G. \& STAFFORD, K. J. 2011. The effects of age and sex on pain sensitivity in young lambs. Applied Animal Behaviour Science, 135, 51-56.

GUESGEN, M. J., BEAUSOLEIL, N. J., MINOT, E. O., STEWART, M. \& STAFFORD, K. J. 2014a. Social context and other factors influence the behavioural expression of pain by lambs. Applied Animal Behaviour Science, 159, 41-49.

GUESGEN, M. J., BEAUSOLEIL, N. J., MINOT, E. O., STEWART, M. \& STAFFORD, K. J. 2014b. Social context and other factors influence the behavioural expression of pain by lambs. Applied Animal Behaviour Science, 159, 41-49.

GUESGEN, M. J., BEAUSOLEIL, N. J., MINOT, E. O., STEWART, M., STAFFORD, K. J. \& MOREL, P. C. H. 2016. Lambs show changes in ear posture when experiencing pain. Animal Welfare, 25, 171-177.

HAMILTON, W. D. 1964. Genetical evolution of social behaviour 2. Journal of Theoretical Biology, 7, 1752.

HENNESSY, M. B., KAISER, S. \& SACHSER, N. 2009. Social buffering of the stress response: Diversity, mechanisms, and functions. Frontiers in Neuroendocrinology, 30, 470-482.

HILD, S., ANDERSEN, I. L. \& ZANELLA, A. J. 2010. The relationship between thermal nociceptive threshold in lambs and ewe-lamb interactions. Small Ruminant Research, 90, 142-145.

HILD, S., CLARK, C. C. A., DWYER, C. M., MURRELL, J. C., MENDL, M. \& ZANELLA, A. J. 2011. Ewes are more attentive to their offspring experiencing pain but not stress. Applied Animal Behaviour Science, 132, 114-120.

JOHNSON, C. B., SYLVESTER, S. P., STAFFORD, K. J., MITCHINSON, S. L., WARD, R. N. \& MELLOR, D. J. 2009. Effects of age on the electroencephalographic response to castration in lambs anaesthetized with halothane in oxygen from birth to 6 weeks old. Veterinary Anaesthesia and Analgesia, 36, 273-279.

Peer) reviewing PDF | (2020:04:48155:2:0:NEW 4 Sep 2020) 
KENT, J. E., MOLONY, V. \& GRAHAM, M. J. 1998. Comparison of methods for the reduction of acute pain produced by rubber ring castration or tail docking of week-old lambs. Veterinary Journal, 155, 39-51.

KIKUSUI, T., WINSLOW, J. T. \& MORI, Y. 2006. Social buffering: relief from stress and anxiety. Philosophical Transactions of the Royal Society B-Biological Sciences, 361, 2215-2228.

LLOYD, J. \& PLAYFORD, M. 2013. A producer's guide to sheep husbandry practices, Sydney, Meat \& Livestock Australian (MLA).

MCCRACKEN, L., WARAN, N., MITCHINSON, S. \& JOHNSON, C. B. 2010. Effect of age at castration on behavioural response to subsequent tail docking in lambs. Veterinary Anaesthesia and Analgesia, 37, 375-381.

MOLONY, V. \& KENT, J. E. 1997. Assessment of acute pain in farm animals using behavioral and physiological measurements. Journal of Animal Science, 75, 266-272.

MONK, J. E., DOYLE, R. E., COLDITZ, I. G., BELSON, S., CRONIN, G. M. \& LEE, C. 2018. Towards a more practical attention bias test to assess affective state in sheep. Plos One, 13.

MONK, J. E., LEE, C., BELSON, S., COLDITZ, I. G. \& CAMPBELL, D. L. M. 2019. The influence of pharmacologically-induced affective states on attention bias in sheep. Peerj, 7.

NICOL, C. J. 1995. The social transmission of information and behavior. Applied Animal Behaviour Science, 44, 79-98.

PAULL, D. R., SMALL, A. H., LEE, C., PALLADIN, P. \& COLDITZ, I. G. 2012. Evaluating a novel analgesic strategy for ring castration of ram lambs. Veterinary Anaesthesia and Analgesia, 39, 539-549.

RAULT, J. L. 2012. Friends with benefits: Social support and its relevance for farm animal welfare. Applied Animal Behaviour Science, 136, 1-14.

REEFMANN, N., KASZAS, F. B., WECHSLER, B. \& GYGAX, L. 2009a. Ear and tail postures as indicators of emotional valence in sheep. Applied Animal Behaviour Science, 118, 199-207.

REEFMANN, N., KASZAS, F. B., WECHSLER, B. \& GYGAX, L. 2009b. Physiological expression of emotional reactions in sheep. Physiology \& Behavior, 98, 235-241.

REEFMANN, N., WECHSLER, B. \& GYGAX, L. 2009c. Behavioural and physiological assessment of positive and negative emotion in sheep. Animal Behaviour, 78, 651-659.

TSIGOS, C. \& CHROUSOS, G. P. 2002. Hypothalamic-pituitary-adrenal axis, neuroendocrine factors and stress. Journal of Psychosomatic Research, 53, 865-871.

VEISSIER, I., BOISSY, A., NOWAK, R., ORGEUR, P. \& POINDRON, P. 1998. Ontogeny of social awareness in domestic herbivores. Applied Animal Behaviour Science, 57, 233-245.

VERBEEK, E., FERGUSON, D., DE MONJOUR, P. Q. \& LEE, C. 2012. Opioid control of behaviour in sheep: Effects of morphine and naloxone on food intake, activity and the affective state. Applied Animal Behaviour Science, 142, 18-29.

WU, C. R., GAVVA, N. R. \& BRENNAN, T. J. 2008. Effect of AMG0347, a transient receptor potential type VI receptor antagonist, and morphine on pain behavior after plantar incision. Anesthesiology, $108,1100-1108$. 
Table $\mathbf{1}$ (on next page)

Outline of study timeline 
1 Table 1: Outline of study timeline

\begin{tabular}{|c|c|}
\hline Time period & Activity \\
\hline Week -2 & $\begin{array}{l}\text { Identification of ewe-offspring groupings by observation of proximity, } \\
\text { following and suckling behaviour in the field, mustering of ewe-offspring } \\
\text { groupings, supplementation of grass feed with animal house pellets. } \\
\text { Animals checked daily }\end{array}$ \\
\hline Week -1 & $\begin{array}{l}\text { Ewe-offspring groupings moved into animal house, lambs weighed, ear } \\
\text { tags recorded, assigned to cohort based on average bodyweight in each } \\
\text { twin pair } \\
\text { Animals fed and checked daily }\end{array}$ \\
\hline Day -1 & $\begin{array}{l}\text { Cohort } 1 \text { lambs weighed, clinical examinations performed and blood } \\
\text { samples assayed, ewe-offspring groups assigned to treatment pen, } \\
\text { identification marks applied to flanks of lambs }\end{array}$ \\
\hline Day 0 & $\begin{array}{l}\text { Animals fed at } 08: 00 \text {, remote video recording started } \\
08: 45 \text { - 09:30 treatments applied; } 1 \text { minute of hand-held video footage of } \\
\text { each animal in each ewe-offspring group collected starting } 10 \text { minutes } \\
\text { after the lamb was returned to the pen; } \\
\text { 14:00 - remote video recording stopped and downloaded, animals } \\
\text { checked. }\end{array}$ \\
\hline Day 1 & Cohort 1 removed from treatment pens, treatment pens cleaned. \\
\hline Day 2 & $\begin{array}{l}\text { Cohort } 2 \text { lambs weighed, clinical examinations performed and blood } \\
\text { samples assayed, ewe-offspring groups assigned to treatment pen, } \\
\text { identification marks applied to flanks of lambs }\end{array}$ \\
\hline Day 3 & $\begin{array}{l}\text { Animals fed at 08:00, remote video recording started } \\
\text { 08:45 - 09:30 treatments applied; } 1 \text { minute of hand-held video footage of } \\
\text { each animal in each ewe-offspring group collected starting } 10 \text { minutes } \\
\text { after the lamb was returned to the pen; } \\
\text { 14:00 - remote video recording stopped and downloaded, animals } \\
\text { checked. }\end{array}$ \\
\hline Day 4 & Cohort 2 removed from treatment pens, treatment pens cleaned. \\
\hline Day 5 & $\begin{array}{l}\text { Cohort } 3 \text { lambs weighed, clinical examinations performed and blood } \\
\text { samples assayed, ewe-offspring groups assigned to treatment pen, } \\
\text { identification marks applied to flanks of lambs }\end{array}$ \\
\hline Day 6 & $\begin{array}{l}\text { Animals fed at 08:00, remote video recording started } \\
\text { 08:45 - 09:30 treatments applied; } 1 \text { minute of hand-held video footage of } \\
\text { each animal in each ewe-offspring group collected starting } 10 \text { minutes } \\
\text { after the lamb was returned to the pen; } \\
\text { 14:00 - remote video recording stopped and downloaded, animals } \\
\text { checked. }\end{array}$ \\
\hline Day 7 & $\begin{array}{l}\text { Cohort } 3 \text { removed from treatment pens, treatment pens cleaned. } \\
\text { All animals returned to farm. }\end{array}$ \\
\hline
\end{tabular}




\section{Table 2 (on next page)}

Behaviour as actors: description of postural behaviours and active pain related behaviours recorded during the experiment, as described by Colditz et al. (2012) 
1 Table 2: Behaviour as actors: description of postural behaviours and active pain related

2 behaviours recorded during the experiment, as described by Colditz et al. (2012)

\begin{tabular}{|c|c|c|}
\hline Behaviour & Abbreviation & Description \\
\hline \multicolumn{3}{|c|}{ Postural behaviours } \\
\hline Normal upright & $\mathrm{Nu}$ & $\begin{array}{l}\text { Standing, walking or playing while exhibiting a usual posture } \\
\text { or gait; smooth movements }\end{array}$ \\
\hline Abnormal upright & $\mathrm{Au}$ & $\begin{array}{l}\text { Standing exhibiting unusual posture e.g. Rounded, hunched } \\
\text { appearance; ataxia; jerky movements; walking unsteadily, } \\
\text { backwards, on knees. }\end{array}$ \\
\hline Total upright & $\begin{array}{l}\text { Sum of: } \\
\mathrm{Nu}+\mathrm{au}\end{array}$ & All upright postures pooled \\
\hline Normal lying & N1 & $\begin{array}{l}\text { Ventral recumbency, all legs tucked under body or very close } \\
\text { to body }\end{array}$ \\
\hline Abnormal lying & $\mathrm{Al}$ & $\begin{array}{l}\text { Twisted lying; ventral recumbency with forelimbs tucked } \\
\text { under body, one or both hind limbs partially or fully } \\
\text { extended; including dog sitting and lateral lying (lateral } \\
\text { recumbency with one shoulder on ground, hind limbs and/or } \\
\text { forelimbs fully extended) }\end{array}$ \\
\hline \multicolumn{3}{|c|}{ Active pain related behaviours } \\
\hline Restlessness & Rst & $\begin{array}{l}\text { Number of times lamb stood up and laid down. Instances of } \\
\text { lamb rising as far as its knees included in the one count. }\end{array}$ \\
\hline $\begin{array}{l}\text { Kicking/foot } \\
\text { stamping }\end{array}$ & Fsk & $\begin{array}{l}\text { Either a front or hind limb (usually hind limb) was lifted and } \\
\text { forcefully placed on the ground while standing or was used to } \\
\text { kick while standing or lying. }\end{array}$ \\
\hline Rolling & $\mathrm{Rl}$ & $\begin{array}{l}\text { Rolled from lying on one side to the other without getting up. } \\
\text { Half rolls where the lamb rolled on its back and then returned } \\
\text { to lying on the same side included. }\end{array}$ \\
\hline Jumping & Jmp & All four feet off ground simultaneously \\
\hline $\begin{array}{l}\text { Licking/biting } \\
\text { wound site }\end{array}$ & Lbw & $\begin{array}{l}\text { Movement of the head beyond the shoulder, including both } \\
\text { looking and touching at the source of pain and grooming. }\end{array}$ \\
\hline Head shake & Sh & Forceful voluntary shake of the head \\
\hline Easing quarters & $\mathrm{Eq}$ & $\begin{array}{l}\text { Abnormally lowers rear quarters (standing) or attempts to } \\
\text { keep quarters off the ground (lying). }\end{array}$ \\
\hline $\begin{array}{l}\text { Sum of Pain } \\
\text { Related } \\
\text { Behaviours }\end{array}$ & $\begin{array}{l}\text { Sum of: } \\
\mathrm{Rst}+\mathrm{fsk}+\mathrm{rl}+\mathrm{j} \\
\mathrm{mp}+\mathrm{lbw}+\mathrm{eq}\end{array}$ & All pain related behaviours pooled. \\
\hline
\end{tabular}




\section{Table 3(on next page)}

Behaviour as observers: description of attention direction behaviours recorded during the experiment. 
1 Table 3: Behaviour as observers: description of attention direction behaviours recorded during

2 the experiment.

Attention behaviour Abbreviation Description

Looking at ewe

Ewe

Head and eyes turned in the direction of the ewe

Looking at twin

Twin

Head and eyes turned in the direction of its twin sibling

Looking at own tail

Tail

Head and eyes turned in the direction of its own tail

Looking elsewhere

Other Head and eyes turned elsewhere than one of the above

Head direction hchanges The number of times head position changed from one of changes the above to another.

3

4 


\section{Table 4 (on next page)}

Behaviour as actors $(n=48)$ : effect of grouping and treatment on pain related and postural behaviours of lambs following treatment

Counts of postural behaviours and pain related behaviour was recorded continuously from 15 till 45 min post-treatment. All data presented are log transformed least squares means with back transformed data in parentheses and $95 \% \mathrm{Cl}$ in square brackets below. There were no significant first-order interactions between pen, cohort and treatment. ${ }^{a, b}$ Means across each row with different superscripts are significantly different $(P<0.005)$. 
Table 4: Behaviour as actors $(\mathrm{n}=48)$ : effect of grouping and treatment on pain related and postural behaviours of lambs following treatment. Counts of postural behaviours and pain related behaviour was recorded continuously from 15 till 45 min post-treatment. All data presented are log transformed least squares means with back transformed data in parentheses and $95 \% \mathrm{CI}$ in square brackets below. There were no significant first-order interactions between pen, cohort and treatment. ${ }^{\mathrm{a}, \mathrm{b}}$ Means across each row with different 5 superscripts are significantly different $(\mathrm{P} \leq 0.005)$.

\begin{tabular}{|c|c|c|c|c|c|c|c|c|c|c|}
\hline \multirow{3}{*}{$\begin{array}{r}\text { Grouping } \\
\text { Actor Lamb } \\
\text { status } \\
\end{array}$} & \multicolumn{5}{|c|}{ Homogeneous } & \multicolumn{5}{|c|}{ Heterogeneous } \\
\hline & \multicolumn{2}{|l|}{ Castrated } & \multicolumn{3}{|l|}{ Not castrated } & \multicolumn{2}{|l|}{ Castrated } & \multicolumn{3}{|l|}{$\begin{array}{l}\text { Not } \\
\text { castrated }\end{array}$} \\
\hline & $\begin{array}{l}\text { Mean (back } \\
\text { transformed } \\
\text { estimate }\end{array}$ & $\mathrm{SE}$ & $\begin{array}{l}\text { Mean (back } \\
\text { transformed } \\
\text { estimate }\end{array}$ & $\mathrm{SE}$ & $\mathrm{P}$ & $\begin{array}{l}\text { Mean (back } \\
\text { transformed } \\
\text { estimate }\end{array}$ & $\mathrm{SE}$ & $\begin{array}{l}\text { Mean (back } \\
\text { transformed } \\
\text { estimate }\end{array}$ & $\mathrm{SE}$ & $\mathrm{P}$ \\
\hline \multicolumn{11}{|c|}{ Postural behaviours } \\
\hline Normal upright & $1.34(21.05)^{\mathrm{a}}$ & 0.05 & $0.33(1.12)^{b}$ & 0.05 & $<0.001$ & $1.35(21.51)^{\mathrm{a}}$ & 0.05 & $0.33(1.14)^{b}$ & 0.05 & $<0.001$ \\
\hline $\begin{array}{l}\text { Abnormal } \\
\text { upright }\end{array}$ & $0.57(2.70)^{\mathrm{a}}$ & 0.06 & $0(0)^{b}$ & 0.06 & $<0.001$ & $0.54(2.44)^{\mathrm{a}}$ & 0.06 & $0(0)^{b}$ & 0.06 & $<0.001$ \\
\hline Total upright & $1.40(23.87)^{\mathrm{a}}$ & 0.05 & $0.33(1.12)^{b}$ & 0.05 & $<0.001$ & $1.41(24.51)^{\mathrm{a}}$ & 0.05 & $0.33(1.14)^{b}$ & 0.05 & $<0.001$ \\
\hline Normal lying & $1.25(16.83)^{\mathrm{a}}$ & 0.06 & $0.19(0.55)^{b}$ & 0.06 & $<0.001$ & $1.23(16.06)^{\mathrm{a}}$ & 0.06 & $0.09(0.23)^{b}$ & 0.06 & $<0.001$ \\
\hline Abnormal lying & $1.07(10.63)^{\mathrm{a}}$ & 0.05 & $0(0)^{b}$ & 0.05 & $<0.001$ & $0.99(8.82)^{\mathrm{a}}$ & 0.05 & $0(0)^{b}$ & 0.05 & $<0.001$ \\
\hline \multicolumn{11}{|c|}{ Active pain related behaviours } \\
\hline Restlessness & $1.43(26.08)^{\mathrm{a}}$ & 0.05 & $0.04(0.10)^{b}$ & 0.05 & $<0.001$ & $1.38(22.99)^{\mathrm{a}}$ & 0.05 & $0.08(0.19)^{b}$ & 0.05 & $<0.001$ \\
\hline $\begin{array}{l}\text { Kicking/foot } \\
\text { stamping }\end{array}$ & $0.79(5.17)^{\mathrm{a}}$ & 0.11 & $0.08(0.19)^{b}$ & 0.11 & $<0.001$ & $0.81(5.44)^{a}$ & 0.11 & $0.03(0.06)^{b}$ & 0.11 & $<0.001$ \\
\hline $\begin{array}{l}\text { Licking/biting } \\
\text { wound site }\end{array}$ & $0.78(5.00)^{\mathrm{a}}$ & 0.09 & $0.23(0.72)^{b}$ & 0.09 & $<0.001$ & $0.56(2.62)^{\mathrm{a}}$ & 0.09 & $0.13(0.33)^{b}$ & 0.09 & $<0.001$ \\
\hline Easing quarters & $0.35(1.21)^{\mathrm{a}}$ & 0.06 & $0.09(0.23)^{b}$ & 0.06 & $=0.005$ & $0.35(1.21)^{\mathrm{a}}$ & 0.06 & $0.08(0.19)^{b}$ & 0.06 & $=0.005$ \\
\hline $\begin{array}{l}\text { Total pain } \\
\text { behaviour }\end{array}$ & $1.63(41.60)^{\mathrm{a}}$ & 0.07 & $0.41(1.60)^{b}$ & 0.07 & $<0.001$ & $1.56(35.53)^{\mathrm{a}}$ & 0.07 & $0.26(0.80)^{b}$ & 0.07 & $<0.001$ \\
\hline
\end{tabular}




\section{Table 5 (on next page)}

Behaviour as observers $(n=48)$ : effect of treatment on attention directed behaviour of lambs for 45 min following treatmen.

Data are mean counts and collected continuously for 1 min at 5 min intervals between 15

and 30 min post-treatment. $95 \% \mathrm{Cl}$ is given in square brackets. ${ }^{a, b, c}$ Means across each row with different superscripts are significantly different $(P<0.01)$. NS: not significant. There were no significant first order interactions between pen, cohort and treatment. * Data presented are log transformed least squares means with back transformed data in parentheses. 
Table 5: Behaviour as observers ( $\mathrm{n}=48$ ): effect of treatment on attention directed behaviour of lambs for $45 \mathrm{~min}$ following treatment. Data are mean counts and collected continuously for $1 \mathrm{~min}$ at $5 \mathrm{~min}$ intervals between 15 and $30 \mathrm{~min}$ post-treatment. 95\% CI is given in square brackets. ab,c, Means across each row with different superscripts are significantly different $(\mathrm{P} \leq 0.01)$. NS: not significant.

4 There were no significant first order interactions between pen, cohort and treatment. ${ }^{*}$ Data presented are log transformed least squares 5 means with back transformed data in parentheses.

\begin{tabular}{|c|c|c|c|c|c|c|c|c|c|c|}
\hline \multirow{2}{*}{$\begin{array}{r}\text { Grouping } \\
\text { Actor Lamb } \\
\text { status } \\
\end{array}$} & \multicolumn{5}{|c|}{ Homogeneous } & \multicolumn{5}{|c|}{ Heterogeneous } \\
\hline & \multicolumn{2}{|l|}{ Castrated } & \multicolumn{3}{|c|}{$\begin{array}{l}\text { Not } \\
\text { castrated }\end{array}$} & \multicolumn{2}{|l|}{ Castrated } & \multicolumn{2}{|c|}{ Not castrated } & \\
\hline \multicolumn{11}{|c|}{ Attention direction } \\
\hline & $\begin{array}{l}\text { Mean (back } \\
\text { transformed } \\
\text { estimate) }\end{array}$ & SE & $\begin{array}{l}\text { Mean (back } \\
\text { transformed } \\
\text { estimate) }\end{array}$ & $\mathrm{SE}$ & $P$ & $\begin{array}{l}\text { Mean (back } \\
\text { transformed } \\
\text { estimate) }\end{array}$ & SE & $\begin{array}{l}\text { Mean (back } \\
\text { transformed } \\
\text { estimate) }\end{array}$ & SE & $\mathrm{P}$ \\
\hline Looking at ewe & $64.25^{\mathrm{a}, \mathrm{b}}$ & 8.92 & $55.67^{\mathrm{a}, \mathrm{b}}$ & 8.92 & NS & $77.50^{\mathrm{a}, \mathrm{b}}$ & 8.92 & $50.25^{b}$ & 8.92 & NS \\
\hline $\begin{array}{l}\text { Looking at } \\
\text { twin }\end{array}$ & $42.50^{\mathrm{a}}$ & 4.35 & $18.00^{b}$ & 4.35 & $=0.006$ & $23.42^{b}$ & 4.35 & $27.75^{b}$ & 4.35 & NS \\
\hline $\begin{array}{l}\text { Looking at } \\
\text { own tail } \#\end{array}$ & $0.74(5.53)^{\mathrm{a}}$ & 0.11 & $0.08(1.76)^{c}$ & 0.11 & $=0.002$ & $\begin{array}{l}0.50(3.16) \\
a, b\end{array}$ & 0.11 & $0.25(1.20)^{b, c}$ & 0.11 & NS \\
\hline $\begin{array}{l}\text { Looking } \\
\text { elsewhere }\end{array}$ & $245.25^{\mathrm{a}}$ & 9.32 & $291.42^{b}$ & 9.32 & $=0.011$ & $255.58^{\mathrm{a}, \mathrm{b}}$ & 9.32 & $275.08^{\mathrm{a}, \mathrm{b}}$ & 9.32 & NS \\
\hline $\begin{array}{l}\text { Head direction } \\
\text { changes }\end{array}$ & $34.08^{\mathrm{a}}$ & 2.40 & $17.67^{b}$ & 2.40 & $<0.001$ & $35.08^{\mathrm{a}}$ & 2.40 & $27.75^{\mathrm{a}}$ & 2.40 & NS \\
\hline
\end{tabular}


Figure 1

Schematic diagram of study design

Diagram of lamb groupings in each of four pens in each cohort. C: castrated lamb; N: noncastrated lamb. Curved arrow shows direction of attention from observer lamb to actor lamb.

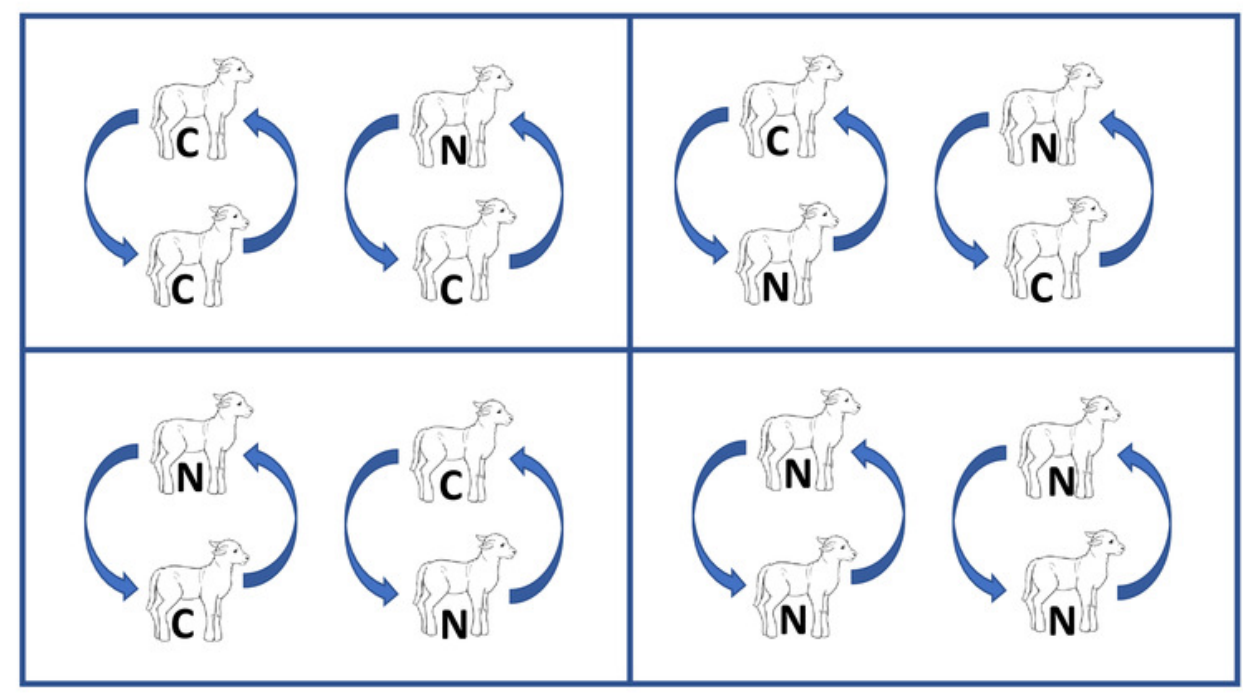

$\mathbf{N}$ not castrated; C castrated; arrow shows direction of observation from observer lamb to actor lamb 